Ewa JURGA-WOSIK

Uniwersytet im. Adama Mickiewicza, Poznań

\title{
Dwie dekady przeobrażeń mediów lokalnych południowo-zachodniej Wielkopolski
}

Ubileusz dwudziestolecia mediów lokalnych w Polsce, powstałych po
1989 r. jest dobrym momentem do podsumowania wydawnictw prasy lokalnej południowo-zachodniej Wielkopolski i jej okolic - historycznie i współcześnie związanych z rynkiem wydawniczym omawianego regionu. Obszar ten znany jest z bogatych tradycji czasopiśmienniczych. Prasa powiatów - leszczyńskiego, gostyńskiego, górowskiego (obecnie woj. dolnośląskie), kościańskiego, rawickiego oraz okolic Wschowy (obecnie woj. lubuskie) w dziejach regionu odegrała znaczącą rolę. Prasa lokalna integrowała społeczność lokalną bez względu na panujące warunki prawne i polityczne. Świadczy o tym wielość tytułów w poszczególnych okresach historii, zakres tematyczny i otwarcie ich na odbiorcę ${ }^{1}$. Należy jasno podkreślić znaczenie inicjatyw prasowych w dziejach południowo-zachodniej Wielkopolski. Powstawały bowiem pisma zarówno w Polsce Ludowej, jak i po 1989 r., które niejednokrotnie nawiązywały tytułem, szatą graficzną i zawartością treści do pierwszych periodyków ukazujących się pod zaborem pruskim („Przyjaciela Ludu”, „Gazety Polskiej”) i w dwudziestoleciu międzywojennym („Gazety Gostyńskiej”, „Ziemi Leszczyńskiej”). Współcześnie prasa lokalna południowo-zachodniej Wielkopolski (wraz z tytułami powstałymi w latach 1989-1998 na obszarze województwa leszczyńskiego) potwierdza także specyfikę funkcjonowania tego typu pism w Polsce ${ }^{2}$. Ponadto, jak wskazują medioznawcy

1 Szerzej: E. Jurga, Prasa lokalna w powiatach-gostyńskim, górowskim, rawickim $i$ wschowskim, w: Prasa dawna i współczesna, pod red. B. Kosmanowej, cz. IV, Poznań 2003, s. 129-141; E. Jurga, Prasa lokalna w Lesznie, w: Z dziejów prasy wielkopolskiej XIX $i$ XX w., pod red. J. Załubskiego, t. V, Poznań 2003, s. 111-131; E. Jurga, Prasa lokalna Ziemi Kościańskiej, w: Prasa dawna i wspótczesna, część druga, pod red. B. Kosmanowej, Poznań 2001, s. 7-23.

2 Por. R. Kowalczyk, Media lokalne i społeczeństwo. Wybrane zagadnienia na przyktadzie prasy lokalnej w Wielkopolsce, Poznań 2003, s. 9-13. 
- „prawdziwe zagłębie prasy lokalnej znajduje się w zachodniej Polsce”3. Warto również zwrócić uwagę na wymierny efekt społecznej roli prasy, czego wyrazem są nagrody i wyróżnienia dla redakcji pism południowo-zachodniej Wielkopolski, przyznawane przez środowiska dziennikarskie.

Zmiany polityczno-prawne po 1989 roku umożliwiły rozwój prasy lokalnej ${ }^{4}$. Parlament uchwalił ustawę o likwidacji dotychczasowego monopolisty na rynku wydawniczym - RSW „Prasa-Książka-Ruch” (22 marzec 1990). Uchylił ustawę o kontroli publikacji i widowisk oraz zniósł jej organy (11 kwiecień 1990 roku). Uległ likwidacji dominujący przez całe lata system prasy państwowo-partyjnej ${ }^{5}$. Na rynku prasowym pojawił się nowy rodzaj wydawcy - osoba fizyczna. Odtąd nie koncesja, lecz rejestracja decyduje o powstaniu pisma. Jednak już w latach 1988-1989 w Polsce zaczęły masowo powstawać tytuły komitetów obywatelskich, stając się później głównym instrumentem wyborów samorządowych. W skali kraju takich inicjatyw było w granicach od 2-2,5 tys. ${ }^{6}$ Większość z nich w maju 1990 r. została zawieszona, a przyczyną stało się rozwiązanie komitetów obywatelskich w regionie. To co stało się z tymi inicjatywami na obszarze ówczesnego województwa leszczyńskiego (południowo-zachodniej Wielkopolski), nie odbiega od ogólnego schematu funkcjonowania prasy komitetów obywatelskich w skali ogólnopolskiej, które trafiły w pierwszej kolejności do rąk prywatnych, a w drugiej - do samorządów ${ }^{7}$. Dwa $\mathrm{z}$ trzech tytułów pozostałych po komitetach obywatelskich na rynku leszczyńskim zostały organami prasowymi lokalnych władz samorządowych - „Wiadomości Wschowskie” (1989-1991, 1991-1992) oraz „Gazeta Górowska" (1990-1992). W latach 1989-1990 obok inicjatyw komitetów obywatelskich powstawały też pisma towarzystw kulturalnych i prasa branżowa, które w większości okazały się efemerydami (np. „Gleba. Pismo Krobskiego Towarzystwa Kulturalnego w Krobi”). Pierwsze nie-

3 A. K. Piasecki, Samorzqd Terytorialny a media lokalne (1990-2002). Próba syntezy, „Zeszyty Prasoznawcze”, nr 1-2, Kraków 2003, s. 146.

4 Por. J. Sobczak, Prawo prasowe - komentarz, Warszawa-Poznań 1992; J. Sobczak, Ustawa o radiofonii i telewizji, Toruń 1996; J. Sobczak, Prawo prasowe $w$ działalności prasy lokalnej, Poznań 1993.

5 S. Dziki, Media w rozwoju historycznym, w: Dziennikarstwo i świat mediów, pod red. Z. Bauera, E. Chudzińskiego, Kraków 2000, s. 37-38.

6 W. Chorązki, Obraz niezależnej prasy lokalnej w Polsce w I połowie 1994 r., Kraków 1994, s. 15-16.

7 A. K. Piasecki, op. cit., s. 141-142. 
zależne, prywatne pisma ówczesnego województwa leszczyńskiego, takie jak - „Głos Leszczyński” czy „Ziemia Wschowska” (pozostała po komitetach obywatelskich 1988-1990), rozpowszechniane na obszarze jednego miasta bądź gminy - nie sprostały kosztom wydawniczym. Zostały one wyparte z rynku czytelniczego przez tygodnik „Panoramę Leszczyńską", powstały pod koniec lat siedemdziesiątych, a zasięgiem obejmujący całe województwo leszczyńskie. Natomiast w latach 1990-1994 zanotowano wzrost prasy samorządowej. Z kolei - od połowy lat dziewięćdziesiątych nasiliła się rywalizacja między tytułami lokalnymi (np. „ABC. Dziennik Informacyjny” konkurował z „Panoramą Leszczyńską”, „Wiadomości Kościańskie” z „Kurierem Lokalnym”, „Przegląd Górowski” z „Gazetą Górowską”, „Słowo Ziemi Wschowskiej” z „Gazetą Wschowską”, późniejszą „Elitą”). Na ich łamach przeciwstawiano interesy miejscowej władzy i opozycji, najczęściej bez kontekstu politycznego ugrupowań wiodących w kraju, operując konkretnymi argumentami odnośnie inicjatyw lokalnych. Wraz z nastaniem wyborów samorządowych w 1998 roku, można już było zaobserwować stabilny rynek prasy lokalnej. Kolejna fala zmian pojawiła się po 2004 roku i miała związek z postępem technologicznym w mediach, powstawaniem na szeroką skalę inicjatyw prasowych $\mathrm{w}$ Internecie i widmem kryzysu gospodarczego w Polsce i na świecie.

W pierwszej połowie 1994 roku na jedno czasopismo w województwie leszczyńskim przypadało aż 15 tys. osób, a dwa lata później - czternaście tys. mieszkańców ${ }^{8}$. Porównując liczbę tytułów z liczbą mieszkańców można stwierdzić, że ówczesne województwo leszczyńskie na równi z tarnowskim jako jedyne w Polsce miały najwyższe wskaźniki nasycenia. W 1997 roku według danych OBP, województwo leszczyńskie znalazło się już na czwartym miejscu z 19 tys. mieszkańców przypadających na jeden tytuł prasowy9. Niektóre z pism sublokalnych w tamtym okresie nie były zarejestrowane w Sądzie Okręgowym. Podobnie nie wszystkie tytuły posiadały Międzynarodowy Znormalizowany Numer Wydawnictwa Ciągłego - ISSN, nadawany przez Bibliotekę Narodową. W 1989 r. liczba leszczyńskich tytułów sięgała dziewięciu, a w grudniu 1998 r.

8 Z. Bajka, Historia prasy lokalnej i jej rozwój po 1989, w: Poradnik dla wydawców i dziennikarzy prasy lokalnej, t. 1, Warszawa 1997, s. 34-35; W. Chorązki, Obraz niezależnej prasy lokalnej w I połowie 1994 roku, Kraków 1994, s. 30.

9 „Wspólnota” 1997, nr 41, s. 16. 
- pięćdziesięciu czterech - (lokalnych było -6 , a sublokalnych -48$)^{10}$. Natomiast w czerwcu 1999 roku, już w nowych realiach administracyjnych było 49 pism (lokalnych - 16, sublokalnych - 33). W nowe tysiąclecie weszło 58 tytułów (lokalnych - 21, sublokalnych - 37). W 2009 roku liczba tytułów zmniejszyła się do 34 (lokalnych - 19, sublokalnych - 15). Natomiast w latach 1989-2011 w powiatach-leszczyńskim, gostyńskim, kościańskim, rawickim oraz górowskim i wschowskim - ukazało się łącznie 103 czasopisma (wraz z prasą parafialną - 14 tytułów), w tym tytułów lokalnych -43 i sublokalnych -60 . W okresie dwóch dekad kolportowano w Lesznie i powiecie leszczyńskim - 33 tytuły lokalne oraz w powiecie gostyńskim - 20, powiecie kościańskim - 18, powiecie rawickim -17 oraz powiecie górowskim -15 i powiecie wschowskim - 14 . Warto też wspomnieć o silnych związkach prasy lokalnej Kościana z powiatem wolsztyńskim, gdzie w ostatnim dwudziestoleciu ukazało się 9 tytułów oraz z powiatem grodziskim - w liczbie 12 tytułów. Z kolei Gmina Kobylin skorzystała z włączenia jej do powiatu krotoszyńskiego w 1999 r., w której to rozpowszechniano 6 tytułów. Niniejsze dane pomijają prasę branżową (ok. 15 tytułów prywatnych związanych z sektorem sportowym i również tyle z reklamowym w okresie dwóch dekad) oraz gazetek szkolnych (ponad 20 tytułów).

Wydawców można podzielić, jak wskazuje R. Kowalczyk łącznie na 14 charakterystycznych grup rodzajowych, z wyróżnieniem czterech stałych typów ${ }^{11}$. Pierwszy z nich to wydawca prywatny (czasopisma osób fizycznych, grup obywateli, spółek cywilnych i spółek z ograniczoną odpowiedzialnościa); drugi - wydawnictwa ukazujące się nakładem różnych stowarzyszeń i fundacji, a zatem organizacji pozarządowych oraz komitetów obywatelskich, czy innych organizacji i ruchów o charakterze politycznym oraz wydawnictwa spółdzielni mieszkaniowych czy spółdzielni pracy; trzeci - pisma wydawane przez samorządy terytorialne (gminne, powiatowe i wojewódzkie) i podległe im jednostki (bezpośrednio lub pośrednio); czwarty - prasa samorządów osiedlowych, sołeckich, szkół i uczelni wyższych, parafii, diecezji i archidiecezji Kościoła rzymsko-ka-

${ }^{10}$ E. Jurga, Prasa lokalna Ziemi Leszczyńskiej, w: Środki masowej informacji w Polsce po likwidacji instytucji cenzury (1990-2000), pod red. J. Adamowskiego, Warszawa 2000, s. 217.

${ }_{11}$ R. Kowalczyk, Prasa lokalna w Wielkopolsce (1990-2010), w: Media dawne i wspótczesne, pod red. B. Kosmanowej, t. V, Poznań 2010, s. 92. 
tolickiego, spółdzielni, przedsiębiorstwa, samorządu gospodarczego, samorządu zawodowego, związku zawodowego i administracji.

W województwie leszczyńskim w 1998 roku (podobnie - od początku lat dziewięćdziesiątych) i w południowo-zachodniej Wielkopolsce po 1999 roku - najwięcej ukazywało się tytułów wydawców samorządowych i podległych im jednostek (łącznie 38 tytułów), następnie prasy prywatnej (łącznie 34 tytuły) oraz towarzystw kulturalnych (łącznie 10 tytułów), a na końcu - innych podmiotów (łącznie 21 tytułów). Ilościowe zmiany ukazujących się tytułów dotyczyły w mniejszym stopniu prasy wydawanej przez samorząd terytorialny lub tworzonej na zamówienie samorządu. A zatem zmiany na rynku inicjatyw prasowych, które dotykały głównie wydawców prywatnych i ukazujących się pod patronatem fundacji, towarzystw kulturalnych - wynikały z trudności finansowych wydawców, wzrastającej konkurencji na rynku prasowym i reklamowym, ale też z konfliktów personalnych w redakcjach. Na krótko ukazały się m.in. „Wiadomości Wąsosza” (1990-1995), „Wiadomości Wschowskie” (1989-1992), „Ziemia Borecka” (1998), „Ziemia Wschowska” (2000), „Nowiny Kościańskie” (2005), „Fakty Górowskie” (2008), „Moja Gazeta Górowska" (2008-2009). Warto też podkreślić istnienie w omawianym okresie działań lokalnych wydawców w kierunku koncentracji rynku lokalnego. Działania takie inicjowała - „Panorama”sp. z o.o. - wcześniej jako Spółdzielnia „Panorama”, Spółka c. Awa Press, Spółka c. Zbigniew Greźlikowski). Wpływ wydawcy na charakter pisma, czyli na jego publikacje, szatę graficzną, dystrybucję, cenę pisma oraz skład redakcji jest niepodważalny. Nie rzadko ten sam wydawca był również redaktorem naczelnym pisma (np. „Gazeta Rawicka” w latach dziewięćdziesiątych, „Kurier Lokalny”). Lata 2000-2010 dla południowo-zachodniej Wielkopolski to również początek koncentracji „wydawniczo-drukarskiej” reprezentowanych przez wydawców regionalnych i ogólnopolskich (Wielkopolska Oficyna Wydawnicza, Polskapresse, Presspublica).

Porównując czasopisma samorządowe i prywatne można dostrzec pewne różnice. W prywatnych pismach jest więcej reklam i ogłoszeń, a w prasie samorządowej występują sporadycznie. Ponadto - większa powierzchnia prasy prywatnej umożliwia zamieszczanie więcej zróżnicowanych tekstów, co wynika chociażby z większej liczby współpracowników. Prasa samorządowa to zwykle miesięczniki, dwumiesięczniki i kwartalniki, a prasa prywatna obejmuje najczęściej tygodniki i dwutygodniki. Wraz ze wzrostem prasy prywatnej zanotowano wzrost cotygodniowej częstotliwości. Dodatkowo wydawcy prywatni posiadają szerszy 
zasięg kolportażu (wkraczając w ościenny powiat województwa wielkopolskiego, dolnośląskiego lub lubuskiego), niejednokrotnie tworząc tygodniki w ich mniemaniu mikroregionalne (np. „Gazeta Kościańska”, „Panorama Leszczyńska”) ${ }^{12}$. W prasie południowo-zachodniej Wielkopolski występują pisma o zróżnicowanej częstotliwości ukazywania się - od dziennika po roczniki. Niemal każde z pism rozpoczynało działalność na formacie A-4 i na takowym kończyło (choć niektóre zmieniały format z większego na mniejszy B-3, np. „Kurier Lokalny”, „Słowo Ziemi Wschowskiej”, „Panorama Leszczyńska”). Prasa lokalna jest sprzedawana detalicznie częściej w placówkach handlowych niż za pośrednictwem sieci kolportażowych (Ruch S.A. i Kolporter S.A.) czy w prenumeracie. Ta ostatnia jest elementem stabilizacji rynkowej pozycji gazety (nawet gdy generowany zysk jest mniejszy poprzez niższą cenę w prenumeracie) i sprzyja rozwijaniu planów długoterminowych. Korzyści z prenumeraty związane są z zapłatą z góry za kolejne wydania i to jest niejako kredyt obrotowy dla wydawcy ${ }^{13}$. O wysokości ceny egzemplarzowej decyduja - popyt, koszty jednostkowe oraz ceny substytucyjnych produktów (dodatków). Cena tytułu lokalnego kształtuje się w granicach od 1 do 3 zł. Niewatpliwie jest ona też optymalizowana w oparciu o kryterium akceptacji jej przez czytelnika przy regularnym zakupie oraz strategii wydawcy.

Prasa lokalna południowo-zachodniej Wielkopolski należy do grupy pism niskonakładowych ${ }^{14}$. Prasa samorządowa i wydawana przez ośrodki

12 Problem definicyjny prasy lokalnej nurtuje wielu badaczy, szczególnie w obliczu pojawienia się prasy nazywanej przez dziennikarzy i niektórych badaczy (np. R. Filasa) - „mikroregionalną”, obejmującą zasięgiem kilka powiatów, często nawiązując do dawnych podziałów na małe ,gierkowskie” województwa (np. „Panorama Leszczyńska"). Oprócz prasy lokalnej w tradycyjnym znaczeniu - istnieje prasa mająca charakter „transgraniczny”, która skorzystała z nowego podziału administracyjnego, obowiązującego od 1999 roku. Odnośnie meandrów definicyjnych szerzej: Dziennikarstwo i świat mediów, red. Z. Bauer, E. Chudziński, Kraków 2000; S. Dziki, Warsztat dokumentacyjny prasoznawcy, Wyd. Ossolineum 1992; W. Chorązi, Media lokalne i sublokalne, „Zeszyty Prasoznawcze”, nr 1-2, Kraków 1999; R. Filas, Dwadzieścia lat przemian polskich mediów (1989-2009) w ujęciu periodycznym, „Zeszyty Prasoznawcze”, nr 3-4, Kraków 2010, s. 33.

13 T. Kowalski, B. Jung, Media na rynku. Wprowadzenie do ekonomiki mediów, Warszawa 2006, s. 126.

14 E. Jurga, Przegląd prasy lokalnej Ziemi Leszczyńskiej, w: Historia bliższa $i$ dalsza. Polityka - społeczeństwo - wojskowość. Studia z historii powszechnej i Polski, pod red. S. Kowala, G. Kucharskiego, M. Walczaka, Poznań-Kalisz 2001, s. $327-345$. 
kultury w większości od początku swojego istnienia nie zwiększyła nakładu, a nawet w przypadku jednostkowych edycji zmniejszyła nakład o 30\%. Wydaje się, że do gry rynkowej włączyły się tylko wydawnictwa prywatne. Pisma popularnonaukowe i publicystyczne takie jak „Przyjaciel Ludu”, „Zeszyty Lubińskie”, „Zeszyty Osieckie” oraz „Rydzyniak” - ze względu na swoją sprofilowaną tematykę - nie potrzebowały wysokich nakładów, by znaleźć stałych czytelników. Większość tytułów nie przekracza 1000 egzemplarzy jednorazowego nakładu. Jedynie „Gazetę ABC” (dawne - „ABC. Dziennik Informacyjny”) oraz tygodnik „Panoramę Leszczyńską" cechuje stosunkowo olbrzymi nakład w porównaniu z innymi tytułami. Jednorazowy nakład „Panoramy Leszczyńskiej” w pierwszej dekadzie przekraczał 50 tysięcy egzemplarzy, a w drugiej - już nieco ponad 30 tys. egzemplarzy. W drugiej dekadzie, rynek prasy drukowanej boryka się z utrzymaniem lojalności czytelników, czego dowodem jest spadek nakładów. W przypadku prasy ogólnopolskiej i regionalnej postępująca konwergencja między tytułami a Internetem rekompensuje malejące nakłady gazet w ich tradycyjnym znaczeniu. Działania w tym kierunku są też realizowane poprzez portal „Panoramy Leszczyńskiej” (panorama.media.pl) i wydawcę Radia Elka.

Tytuły wychodzące w dwóch ostatnich dekadach można sklasyfikować według ilości nakładu. Pierwsza grupa pism, nie przekraczała 500 egzemplarzy (prasa popularnonaukowa i publicystyczna oraz samorządowa), to m.in.: „Pakosław i okolice”, „Przegląd Górowski”, „Wiadomości Jutrosińskie”, „Wieści Gminne”, „Wieści Krzywińskie”, „Wizja lokalna” oraz gazety parafialne. Pismami mającymi nakład w przedziale od 501 do 1100 egzemplarzy były m.in.: „Gazeta Rawicka”, „Gazeta Górowska” (1995-1998), „Informator Samorządowy Miasta i Gminy Bojanowo”, „Kobylin. Pismo Samorządu Miasta i Gminy”, „Kurier Osiecki”, „Kurier Przemęcki”, „Nowiny Niechlowskie”, „Prosto z Gminy. Szlichtyngowski Serwis Informacyjny”, „Rydzyna Tu i Teraz”, „Wieści Pępowa”, „Witryna Śmigielska”, „Ziemia Borecka”. Nakład powyżej 1101 egzemplarzy posiadały m.in. czasopisma: „Panorama Leszczyńska, ABC” wraz z mutacjami - „Gostyńskie ABC”, „Górowskie ABC”, „Kościańskie ABC”, „Rawickie ABC”, „Wschowskie ABC”, a także - „Elita”, „Gazeta Gostyńska”, „Gazeta Górowska” (1999-2000), „Gazeta Kościańska”, „Gazeta Wschowska” (1994-1998), „Kurier Lokalny”, Merkuriusz Leszczyński”, „Nad Obrą”, „Nasze Jutro”, „Obserwator Rawicki”, „Słowo Ziemi Wschowskiej”, „Wiadomości Kościańskie”, „Wiadomości Miejskogóreckie”, „Wschowskie Wiadomości”, „Życie Gostynia” i „Życie Rawicza”. 
Znaczne wahania nakładów w ramach powyższego podziału $\mathrm{z}$ tendencją spadkową są w poszczególnych latach widoczne zwłaszcza w przypadku czasopism samorządowych.

Czasopisma lokalne w drugiej połowie lat dziewięćdziesiątych przeszły ze stosowania kserodruku lub linotypu na skład komputerowy, z zastosowaniem techniki druku typu offset. Pierwsze lokalne pisma po 1989 roku redagowano na maszynie, a powielano na kserokopiarkach. Tylko nieliczne (np. „Ziemia Wschowska”, „Wiadomości Wschowskie”) drukowano. W ten sam sposób w latach dziewięćdziesiątych powstają gazetki szkolne i parafialne ${ }^{15}$. Kserowane były również trzy miesięczniki samorządowe: „Informator Samorządowy Miasta i Gminy Bojanowo”, „Prosto z Gminy - Szlichtyngowski Serwis Samorządowy” oraz „Wieści Gminne" (Jemielno). W następnych latach wysyłano pisma do druku. Początek 2001 roku to również upowszechnianie składania prasy techniką komputerową (np. w „Witrynie Śmigielskiej”). Pod koniec lat dziewięćdziesiątych zaobserwowano zjawisko koncentracji prasy lokalnej i sublokalnej przez miejscowe drukarnie. Obecnie rynek zweryfikował również tę kategorię przedsiębiorców. Odległość drukarni od siedziby redakcji w kontekście dostępności do multimediów i ich wykorzystania nie ma już większego znaczenia. Dla wszystkich kategorii wydawców, bez względu na istniejący system różnego rodzaju dotacji na działalność wydawnicza, zawsze liczy się ostateczny wynik finansowy.

Niezależność finansowa, a dotyczy to w większości prasy wydawców prywatnych, motywuje do poszukiwania korzystnych rozwiązań w zakresie polityki cenowej. Niezmiennie od pierwszej dekady istnienia pism lokalnych po 1989 r. źródłami finansowania przedsięwzięć prasowych pozostają - sprzedaż egzemplarzowa i wpływy z reklam. Powszechnie wiadomo, że duże koncerny mają w tym zakresie większe możliwości, aniżeli małe wydawnictwa. Koncerny prasowe takie jak Agora czy Polskapresse (część koncernu Verlagsgruppe Passau) na drodze swojego rozwoju utworzyły sieci własnych drukarni. Z jednej strony gwarantują one wydawcy zmniejszenie kosztów druku swoich tytułów, a z drugiej strony zwiększenie przychodów o wpływy z druku tytułów należących do innych wydawnictw. W związku z tym druga dekada funkcjonowania mediów lokalnych przyniosła wiele zmian, a w szerszym kontekście, także

15 Wyjątkami były tytuły parafialne: „Być bliżej” (Śmigiel), „Genezaret” (Rawicz), „Głos Świętego Jana” (Leszno), „Quovadis” (Kościan), „Wiadomości Parafialne" (Gostyń) - drukowane kolejno w: Lesznie, Rawiczu, Kościanie i Gostyniu. 
w kategorii - ekonomiki mediów ${ }^{16}$. Prasa lokalna południowo-zachodniej Wielkopolski korzysta z drukarni Agory w Pile („Panorama Leszczyńska”, „Życie Gostynia”, „Życie Rawicza”), Presspublica w Koninku („Kurier Lokalny”, „Kurier Gostynia”) oraz w Polskapresse w Skórzewie („Gazeta ABC”, Dodatek!, „Gazeta Kościańska”). Grupy medialne i koncerny $\mathrm{w}$ dalszym ciągu inwestują $\mathrm{w}$ media lokalne. Jedną z pierwszych transakcji w południowo-zachodniej Wielkopolsce było wykupienie przez Oficynę Wydawniczą „Głosu Wielkopolskiego” mniejszościowego pakietu własnościowego redakcji „Gazety Kościańskiej” (wydawana jest obecnie przez Kościańską Oficynę Wydawnicza), „Życia Gostynia” i „Życia Rawicza” (obydwa tytuły wydaje Południowa Oficyna Wydawnicza $)^{17}$. Podobnie jak koncerny, mniejsze wydawnictwa lokują swoje zasoby kapitałowe w Internet. Swoistą formą współpracy są też porozumienia niezależnych wzajemnie mediów lokalnych co do zamieszczania wspólnych reklam, druku w jednej drukarni czy kolportowaniu wspólnego dodatku telewizyjnego czy branżowego np. dotyczącego rolnictwa (m.in. „Panorama Leszczyńska” i „Gazeta Kościańska” partycypują we wspólnym dodatku telewizyjnym - „Tele Wizja”) ${ }^{18}$. Poszczególne wydawnictwa również dołączają do swoich macierzystych tytułów dodatki branżowe (np. Południowa Oficyna Wydawnicza wydaje miesięcznik „Wieści Rolnicze”). Nową tendencją w pozyskiwaniu środków finansowych staje się emisja akcji (debiuty koncernów - Agory S.A. i Grupy Wydawniczej Infor S.A. na Giełdzie Papierów Wartościowych), ale też łatwość uzyskiwania przez wydawnictwa kredytów bankowych ${ }^{19}$.

Posiadanie pokaźnego kapitału ułatwia działalność medialną, szczególnie w kontekście wprowadzania innowacji (zwłaszcza technologicznych), większe możliwości kreowania marki i bardziej wydajne zastosowanie zasobów. Z tym problemem wiąże się zjawisko uzależnienia wydawcy od

16 Ekonomika mediów - w uproszczeniu - zgłębia problematykę, jak rynek i pieniądze funkcjonują w mediach - szerzej: T. Kowalski, B. Jung, op. cit.

17 M. Piechocki, Problem koncentracji na poznańskim rynku prasy, w: Prasa dawna $i$ współczesna, pod. red. B. Kosmanowej, t. V, Poznań, s. 167.

18 R. Majewski, Procesy integracyjne wydawców wielkopolskich, w: Prasa lokalna w budowie społeczeństwa obywatelskiego. Materiaty z konferencji zorganizowanej przez Komisję Kultury i Środków Przekazu przy wspóludziale Izby Wydawców Prasy pod patronatem Marszałka Senatu RP Longina Pastusiaka 21 września 2004 r., Kancelaria Senatu 2005, s. 52-54.

19 M. Kaczmarczyk, D. Szastak-Zięba, Zarzqdzanie redakcja prasowa, Sosnowiec 2009, s. 79. 
źródła finansowania, szczególnie znajdującego się poza granicami kraju lub od lokalnych środowisk politycznych i biznesowych. W takim przypadku trudno o niezależne dziennikarstwo, czego przejawem jest zawartość treści, kiedy ekonomiczny interes przeważa nad rzetelnym i obiektywnym dziennikarstwem. W przypadku prasy lokalnej kwestia uzależnienia od dysponentów lokalnych dotyczy również, choć w mniejszym stopniu prasy prywatnej. W tytułach lokalnych jest stosowana autocenzura. Dziennikarz wie jakich tematów ma unikać. W perspektywie czasu czytelnik zauważa te zależności, czego konsekwencją może być spadek sprzedaży, następnie nakładu, zmiana częstotliwości pisma, i wreszcie odejście reklamodawców. Umiejętność zachowania równowagi w komponowaniu zawartości treści jest łatwiejsza dla prasy lokalnej prywatnej. Inicjatywy samorządowe bądź ukazujące się pod auspicjami różnych towarzystw coraz częściej traktują swoją działalność w charakterze biuletynów informacyjnych, mających na celu kształtowanie wizerunku określonej opcji lokalnej. W dłuższej perspektywie nie służy to społeczeństwu, ani wartościom ekonomicznym pisma, o ile takie mu przyświecają. Jednak z uwagi na znikomą ilość reklamodawców i ogłoszeniodawców w prasie samorządowej, jedynym rozwiązaniem istnienia tego pisma na rynku staje się jego dotowanie i bezpłatny obieg (np. „Gostyńskie Wieści z Ratusza”, „Magazyn Samorządowy Gminy Borek Wielkopolski”, „Przegląd Górowski”, „Nowiny Niechlowskie”). Z drugiej strony istnieje też prywatna prasa lokalna bezpłatna (np. „Kalejdoskop Leszczyński”, „Dodatek”, „Kurier Gostynia”, „Lokalna. Kościan”, „Gazeta Gostyńska” - w 2006 r.) utrzymująca się głównie z rynku reklamowo-ogłoszeniowego.

Dziennikarze południowo-zachodniej Wielkopolski pracują w redakcjach kilkuosobowych $^{20}$. Struktura redakcji kształtuje komunikację pomiędzy jej poszczególnymi elementami. W praktyce wydawnictwa lokalne posiadają zazwyczaj strukturę liniową płaską, która charakteryzuje się małą ilością szczebli hierarchicznego zarządzania ${ }^{21}$. Zaletą jest więc zbliżenie kierownictwa do bezpośrednich wykonawców i tym samym skrócenie drogi przesyłania poleceń oraz przeprowadzania kontroli. W typowej redakcji lokalnej występuje brak specyfikacji zawodowej, a zatem dziennikarze zajmują się wszystkimi elementami procesu redakcyjno-wydawniczego (od redagowania poprzez składanie gazety po

20 E. Jurga, Dziennikarze wielkopolskiej prasy lokalnej w III RP, w: Prasa dawna i współczesna, pod red. B. Kosmanowej, cz. V, Poznań 2004, s. 95-106.

21 M. Kaczmarczyk, op. cit., s. 149. 
kolportaż). W tej materii jednak zdarzają się wyjątki. Wymienić należy gazety wydawców prywatnych o stosunkowo dużym nakładzie i zasięgu kolportażu (biorąc pod uwagę możliwości nasycenia rynku lokalnego tytułami prasowymi), takie jak np.: „Panorama Leszczyńska” czy „Nowa Gazeta Gostyńska",22. W tej prasie najczęściej wyróżnia się cztery działy spełniające wyspecjalizowane funkcje i zadania: redakcyjny (wydawniczy), techniczny (produkcyjny), reklamowy (w tym promocji i marketingu) i kolportażowy (dystrybucji i sprzedaży). Poza redaktorem naczelnym istotną funkcję w prasie lokalnej południowo-zachodniej Wielkopolski pełni redaktor techniczny - odpowiedzialny za skład, łamanie i druk pisma. Pozostali członkowie redakcji odpowiadają za przydzielone im zadania. Rzadko natomiast w redakcjach powoływano zastępcę redaktora. Podobna sytuacja dotyczy sekretarza redakcji, który odpowiada za organizację redakcji, a szczególnie za terminowe zebranie i przygotowanie materiałów prasowych lub wykonanie korekty do kolejnej edycji pisma. Warto również nadmienić, iż podążając za innowacjami w sferze technologii, zmieniła się po 2004 r. (wtedy też zaczęto tworzyć gazety lokalne w Internecie) struktura zatrudnienia w obrębie redakcji, zwłaszcza wydawców prywatnych i wszystkich instytucji, które tworzą infrastrukturę mediów.

Dziennikarze lokalni wywodzą się z różnych środowisk zawodowych. $\mathrm{W}$ prasie samorządowej będą to $\mathrm{W}$ większości pracownicy instytucji samorządowych, ośrodków kulturalnych czy bibliotek. Natomiast w prasie prywatnej przeważają dziennikarze, parający się piórem już w latach osiemdziesiątych, a niekiedy i siedemdziesiątych. Wielu z nich zasilało redakcje lokalne i regionalne w Polsce Ludowej, by później bez wahania podjąc się tworzenia pierwszej wolnej prasy w III RP. Do grona najbardziej znanych dziennikarzy należą - Halina Sicińska („Życie Nadobrza”, „Panorama Leszczyńska”, „ABC. Dziennik Informacyjny”, „Życie Gminy Krzemieniewo”), Tadeusz Jąder („Gazeta Kościańska”, „Merkuriusz Leszczyński”, „Gazeta Poznańska o. Leszno”, „Wiadomości Kościańskie”), Szczepan Ławniczak („ABC”, „Gazeta Poznańska o. Leszno”, „Głos Wielkopolski o. Leszno”, „Przegląd Regionalny”), Roman Majewski („Gazeta Poznańska o. Leszno”, „Panorama Leszczyńska”, „Cztery

22 E. Jurga, Prasa lokalna Ziemi Leszczyńskiej, w: Media i dziennikarstwo na przełomie stuleci. Wybrane zagadnienia, pod red. W. Cisaka, Poznań 2004, s. 77-85; E. Jurga, Odbiorcy prasy lokalnej Ziemi Leszczyńskiej (stan na 2001 r.), w: W kręgu mediów i polityki, pod red. D. Piontek, Poznań 2003, s. 63-83. 
Koła”, „Ziemia Wschowska”, „Przyjaciel Ludu”), Antoni Neczyński („Gazeta ABC”, „Panorama Leszczyńska”), Adama Podsiadły („Przegląd Regionalny”, „Merkuriusz Leszczyński”, „Gazeta Poznańska o. Leszno”), Jerzy Wizerkaniuk („Gazeta Kościańska”, „Nad Obrą”, „Wiadomości Kościańskie”, „Gazeta Poznańska o. Leszno”), Jerzy Zielonka („Panorama Leszczyńska”, „Gazeta Poznańska o. Leszno”, „Przyjaciel Ludu”, „Wiadomości Kościańskie”), Bogdan Ludowicz (fotoreporter - „Gazeta Kościańska”, „Panorama Leszczyńska”) oraz Andrzej Rutecki ps. „Andrzej Jędrol” („ABC. Dziennik Informacyjny”, „Głos Wielkopolski o. Leszno”, „Wiadomości Kościańskie”). Nagła śmierć tego ostatniego w 1999 r. skłoniła dziennikarzy i środowisko regionalistów do ustanowienia Konkursu Dziennikarskiego o Nagrodę im. Andrzeja Ruteckiego (od 1999 r.) $)^{23}$. Dziennikarze i redakcje prasy lokalnej południowo-zachodniej Wielkopolski byli niejednokrotnie wyróżniani i nagradzani w wielu konkursach (m.in. redakcja „Wiadomości Kościańskich” na czele z Jerzym Wizerkaniukiem, który to również w związku z „Gazetą Kościańską" otrzymał nagrodę za „walkę o godność zawodu dziennikarza" 24 , czy jako osobowość dziennikarska - redaktor Jerzy Zielonka ${ }^{25}$ i za cykl artykułów z zakresu dziennikarstwa śledczego - Marta Krzyżanowska-Sołtysik ${ }^{26}$, będąca w zespole „Panoramy Leszczyńskiej”).

Należy jednak podkreślić zróżnicowane przygotowanie do zawodu dziennikarza. Generalnie mimo braku profesjonalnego przygotowania do

23 Np. w 2000 r. nagrodę w kategorii Nadzieje otrzymała gostyńska gazetka szkolna „Schizol”, w kategorii Dziennikarze - Arek Jakubowski („ABC”), a medialną Osobowościq Roku został Zdzisław Moliński, kustosz rydzyńskiego zamku.

24 http://panorama.media.pl/content/view/238499/38, odczyt 5.07.2011 r. W pierwszej połowie lat dziewięćdziesiątych „Wiadomości Kościańskie” zostały nagrodzone przez amerykańską fundację Instytut na rzecz Demokracji w Europie Wschodniej (IDEE). Fundacja ta oceniła wysoki poziom wydawniczy tytułu (szata graficzna oraz treści merytoryczne), istnienie kilkuosobowego stałego zespołu pracowników czy właścicieli pisma oraz jego silne umocowanie w realiach politycznych i ekonomicznych swojego obszaru. Jerzy Wizerkaniuk otrzymał również w 2008 r. „Dziennikarskie Koziołki” od Stowarzyszenia Dziennikarzy Prasy Lokalnej (oddział Wielkopolska) w związku z „Gazetą Kościańską” za „walkę o godność zawodu dziennikarza”.

25 Osobowość dziennikarska - Dziennikarskie Koziołki 2010 Stowarzyszenia Prasy Lokalnej, oddział Poznań, szerzej - http://www.dziennikarze.poznan.pl/index.php?g=6\&idn=38.

26 Marta Krzyżanowska-Sołtysik została nagrodzona w ogólnopolskim konkursie dla dziennikarzy śledczych „Tylko ryba nie bierze?”, szerzej - http://elka.fm/index.php?option=com_content\&task=view\&id=1387\&Itemid=1, odczyt 5.07.2011 r. 
tworzenia czasopism lokalnych (z kilkoma wyjątkami), to zazwyczaj dziennikarze lokalni dysponują dobrymi źródłami informacji i cechuje ich spora determinacja. W pierwszej połowie lat dziewięćdziesiątych to wystarczyło do budowania lokalnego wydawnictwa. Na dalszy plan odsunięto sprawy finansowe i nierzadko rejestrację czasopisma, co dzisiaj wydaje się to niemożliwe. Obecnie wiarygodność pisma jest niezwykle ważnym elementem w pozyskiwaniu czytelników i reklamodawców. W związku z tym redakcje zabiegają o wyróżnienie ich jako przedsiębiorstwa medialnego, postępując zgodnie z zasadami marketingu medialnego $^{27}$. Stąd też „Panorama Leszczyńska” uzyskała certyfikat Wielkopolskiej Jakości, przyznawanej przez Unię Wielkopolan, jest członkiem Izby Wydawców Prasy, Związku Kontroli i Dystrybucji Prasy (nakład jest kontrolowany), poddaje się Polskim Badaniom Czytelnictwa i realizuje ideały Kodeksu Wydawców Prasy. To wszystko sprawia, że taki tytuł - potrafi świadomie kontrolować zmieniające się warunki prasowe na rynku. Dowodem tego jest m.in. umiejętność kształtowania własnego nakładu. Otóż jeszcze w 1995 r. średni nakład „Panoramy Leszczyńskiej” wynosił 56 tysięcy egzemplarzy, a obecnie 33532 egz., przy rozpowszechnianiu ogółem $22688^{28}$. Jak wskazują medioznawcy zwroty do 30\% nakładu generuja jeszcze $\mathrm{zysk}^{29}$.

Warto zwrócić uwagę, iż w wyniku działań dziennikarza Jerzego Wizerkaniuka, wywodzącego się ze środowiska dziennikarzy południowo-zachodniej Wielkopolski, może nastapić zmiana interpretacji prawa prasowego odnośnie autoryzacji ${ }^{30}$. Redaktor odpowiadał w 2004 roku przed sądami - rejonowym i okręgowym w Poznaniu za opublikowanie bez autoryzacji w 2003 r. dosłownie cytowanych wypowiedzi posła SLD Tadeusza Mylera $^{31}$. Zamieścił też bez jego zgody zdjęcia zrobione podczas wywiadu. Sądy umorzyły warunkowo postępowanie karne, ale Wizerkaniuk zaskarżył do Trybunału Konstytucyjnego przepisy Prawa prasowego (art. 49 w zw. z art. 14 ust. 1 i 2), stanowiące podstawę obu orzeczeń. W 2005 roku Jerzy Wizerkaniuk skierował skargę do Trybu-

27 Por. A. Jupowicz-Ginalska, Marketing medialny, Warszawa 2010.

$28 \mathrm{http}: / / w w w . l e s z n o . i n t e r b i t . p l / t e k s t y /$ panorama.htm; http://www.mediabuy.pl/prasa/Panorama_Leszczynska, odczyt 6.06.2011 r.

29 M. Kaczmarczyk, op. cit., s. 86.

30 http://www.spl.top.pl/prawo_prasowe_art2.html, odczyt 5.07.2011 r.

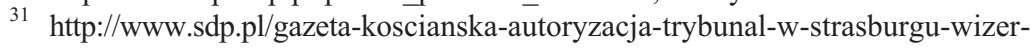
kaniuk, odczyt 5.07.2011 r. 
nału Konstytucyjnego oraz do Europejskiego Trybunału Praw Człowieka w Strasburgu. Dziennikarza poparł Rzecznik Praw Obywatelskich, który oficjalnie przyłączył się do jego skargi do Trybunału Konstytucyjnego. W skardze Jerzy Wizerkaniuk domagał się, aby Trybunał uznał, że przepis przewidujący odpowiedzialność karną za naruszenie przepisów o autoryzacji (art. 49 Prawa prasowego) ingeruje w prawo do swobody wypowiedzi, godzi w zasadę wolność słowa i jest niezgodny z Konstytucją. Jeśli Trybunał przychyliłby się do tej skargi, to artykuł zobowiązujący dziennikarza do autoryzacji (art. 14 ust. 1 i 2 Prawa prasowego) - stałby się martwy, bo nie będzie już zagrożony żadną sankcją ${ }^{32}$. Jednak Trybunał Konstytucyjny uznał w 2008 r. za zgodne z konstytucją przepisy Prawa prasowego o autoryzacji ${ }^{33}$. Wyrok Trybunału Konstytucyjnego zakończył postępowanie krajowe w sprawie autoryzacji, lecz sprawa wyroku skazującego wydanego w oparciu o przepisy Prawa prasowego była jeszcze rozpatrywana przez Trybunał Europejski w Strasburgu dnia 5 lipca 2011 r. Wyrok Trybunału w Strasburgu przeciwko Polsce, która naruszyła swobodę wypowiedzi dziennikarza -usatysfakcjonował redaktora Jerzego Wizerkaniuka. Zdaniem Trybunału w Strasburgu - autoryzacja jest sprzeczna z zasadą swobody wypowiedzi redaktora, a zatem narusza art. 10 Europejskiej Konwencji Praw Człowieka ${ }^{34}$. Sędziowie orzekli, że

$32 \mathrm{http}: / /$ www.veniremedia.pl/a/szkodliwy_przepis, odczyt 5.07.20011 r.

$33 \mathrm{http} / / /$ wyborcza.pl/1,75515,5770102,Zle skutki_autoryzacji.html; http://wiadomosci.gazeta.pl/Wiadomosci/1,80708,5747930,TK_przepisy_dotyczace_autoryzacji_zgodne_z_konstytucja.html, odczyt 10.08.2008 r.

${ }_{34}$ Autoryzacja to przeżytek. Prawo. Redaktor ,GK” wygrat proces w Strasburgu, „Panorama Leszczyńska”, nr 27 (1638), czwartek-środa 7 VII-13 VII 2011, s. 3; http://www.koscian.net/Wizerkaniuk_wygral_w_Strasburgu,6656.html.html; http://elka.pl/content/view/50310/79/; http://www.leszno24.pl/J._Wizerkaniuk_wygral_w_Strasburgu,8207.html; http://stooq.pl/n/?f=482740; http://prawo.gazetaprawna.pl/artykuly/528827,trybunal_w_strasburgu_nie_mozna_karac_dziennikarza_za_publikacje_bez_autoryzacji.html; http://www.polskatimes.pl/fakty/423216,beda-zmiany-w-prawie-prasowym-trybunal-w-strasburgu-nie,id,t.html; http://m.wiadomosci.gazeta.pl/Wiadomosci/1,106024,9896962,Trybunal_w_Strasburgu_nie_karac_za_publikacje_bez.html; http://www.wiadomosci24.pl/artykul/strasburg_trybunal_nie_ukaral_za_publikacje_ bez_autoryzacji_201469.html; http://www.gloswielkopolski.pl/aktualnosci/423239,naczelny-gazety-koscianskiej-wygral-w-strasburgu,id,t.html; http://www.dzienniklodzki.pl/tag/wizerkaniuk.html?cookie=1; http://www.rp.pl/artykul/683394.html?print=tak; http://www.gazetakrakowska.pl/tag/jerzy-wizerkaniuk.html?cookie=1; http://www. polskieradio.pl/5/3/Artykul/396951,Polska-skazana-za-ograniczanie-wolnosci-slowa; http://wiadomosci.dziennik.pl/wydarzenia/artykuly/344370, trybunal-stanal-po-stronie-dziennikarza-autoryzacja-zbedna.html; http://www.dziennikbaltycki.pl/tag/autoryza- 
nie można karać dziennikarza za publikację nieautoryzowanego wywiadu, co więcej - polskie Prawo prasowe przewidujące kary za brak autoryzacji nie przystaje do standardów funkcjonowania społeczeństwa demokratycznego, ze znaczeniem jakie ma pełnić w nim - wolność słowa. Dzięki niemu Prawo prasowe w Polsce winno być zmienione, a obowiązek autoryzacji zniesiony (za - M. Zarembą - przepis odnośnie autoryzacji winien być skreślony) ${ }^{35}$. Zdaniem Michała Zaremby, autora skargi do TK i TE: „dzięki determinacji redaktora Wizerkaniuka pojawiła się szansa na wyeliminowanie jednej z najbardziej szkodliwych dla wolności słowa i prasy konstrukcji prawnej, jaką jest tzw. autoryzacja. Ten nieznany w innych systemach prawnych instrument pozwala każdemu rozmówcy dziennikarza zablokować publikację wywiadu. [...] Wyrok dotyczy oczywiście tylko sytuacji prawnej red. Wizerkaniuka, jednak uzasadnienie Trybunału podważa samą istotę tej konstrukcji prawnej. [...] Jeżeli zatem poważnie traktować członkostwo Polski w Radzie Europy, przepisy te nie powinny już być stosowane przez organy ścigania"36.

Artykuły zamieszczane w prasie lokalnej południowo-zachodniej Wielkopolski najczęściej opisują życie społeczne, w tym wydarzenia kulturalne, wypadki losowe, ale także zagadnienia - dotyczące samorządu terytorialnego i historii regionu ${ }^{37}$. Na uwagę zasługują szczególnie lata 1995-1998, kiedy to w sposób permanentny widać było zaangażowanie prasy lokalnej w problematykę reformy samorządowej, szczególnie tam gdzie społeczności walczyły o utworzenie powiatu (np. sprawa restytucji powiatu wschowskiego), utrzymania województwa lub zmiany swojej przynależności administracyjnej. Po 1999 roku coraz więcej miejsca na

cja-niekonieczna.html; http://www.sdp.pl/gazeta-koscianska-autoryzacja-trybunal-w-strasburgu-wizerkaniuk; http://www.fakty.im1.pl/tagi/Europejska/; http://www.pably.pl/blog/polski-dziennikarz-ma-rece-zwiazane-prawem-prasowym-to-spadek-po-dyktaturze-\%E2\%80\%93-uslyszelismy-w-strasburgu; http:/www.gazetawroclawska.pl/tag/wyrok-w-strasburgu.html?cookie=1; http://wiadomosci.gazeta.pl/Wiadomosci/1,80277,9896962,Trybunal_w_Strasburgu_nie_karac_za_publikacje_bez.html; http://www.wprost.pl/ar/251960/Trybunal-w-Strasburgu-autoryzacja-to-naruszenie-wolnosci-wypowiedzi/?K=1\&N=1, odczyt 5.07.2011 r.

35 http://sdp.salon24.pl/322935,zaremba-o-trybunale-w-strasburgu-i-autoryzacji, odczyt 10.07.2011 r.

36 Ibidem.

37 E. Jurga, Prasa Ziemi Leszczyńskiej jako instrument kształtowania opinii publicznej, w: Kulturowe instrumentarium panowania, pod. red. R. Paradowskiego, P. Załęckiego, Toruń 2001, s. 139-155. 
łamach prasy prywatnej i różnego rodzaju towarzystw zajmują: reklamy i ogłoszenia. Pisma od początku istnienia mają raczej charakter informacyjny i rozrywkowo-reklamowy. Informacja, a w niej notatka, kalendarium i wywiad, jest podstawowym przekazem prasy lokalnej. Niewielki stopień nasycenia prasy lokalnej gatunkami publicystycznymi wynika z wewnętrznej cenzury i niskiego poziomu wykształcenia odbiorcy, dla którego wyrafinowane publikacje byłyby niezrozumiałe. Fenomen rozrywki zaś polega na zamieszczaniu krzyżówek dla dorosłych i dzieci, rebusów, horoskopów i tekstów satyrycznych. Zainteresowanie reklamą i ogłoszeniem wynika nie tylko z merkantylnych dążeń redakcji, ale też z rosnącego zapotrzebowania czytelnika na tego typu publikacje. Prasa lokalna kilkakrotnie w ciagu ostatnich dwóch dekadach zmieniła nie tylko szatę graficzną, ale też sposób prezentacji treści (dotyczących np. kampanii politycznych, partycypacji kobiet w życiu codziennym i publicznym czy zainteresowaniu kwestiami uczestnictwa Polski w Unii Europejskiej). Ten ostatni problem był niezwykle istotny, gdyż badania wskazały, iż najwięcej nieprzekonanych odnośnie przystąpienia Polski do Unii Europejskiej było mieszkańców małych miast i gmin ${ }^{38}$. Zmiany szaty graficznej i sposobu prezentacji treści częściej zachodziły w prasie prywatnej, aniżeli w samorządowej czy wydawanej pod auspicjami różnych towarzystw. Nowości technologiczne sprawiły m.in. poprawę czytelności druku i jakości druku zdjęć. Poza tym dostrzeżono, iż wygląd zewnętrzny pisma jest jednym z najważniejszych elementów strategii działania. Należy jednak pamiętać, że każda modyfikacja, mająca na celu ponowne skupienie uwagi czytelników, pociąga za sobą pewne ryzyko. Zmiana makiety czy zmiana zawartości pisma może oznaczać nową strukturę audytorium. Może się tak zdarzyć, że część odbiorców oczekuje postawy konserwatywnej, wierności koncepcji pisma, a inni-modyfikacji. Nieumiejętność określenia celu i audytorium może oznaczać przeniesienie zainteresowań czytelników na tytuły konkurencyjne, a w ostateczności doprowadzić do niepowodzenia pisma i jego zniknięcia z rynku.

Prasa lokalna południowo-zachodniej Wielkopolski poprzez funkcje: informacyjną, kontrolną, socjalizacyjno-wychowawczą, kulturalną, rozrywkową i reklamowo-ogłoszeniową aktywnie wpływa na opinie, postawy i zachowania odbiorców. Integruje społeczność lokalną wokół jakiejś idei czy wydarzenia, przyjmując również postawę patronatu. Podstawo-

38 Por. J. Kapsa, Media lokalne, pieniadze unijne, „Wspólnota” 2000, nr 13. 
wym zadaniem prasy lokalnej jest przekazywanie treści, które są aktualne, ważne, obiektywne i rzetelnie przedstawione. Nie zawsze te warunki są spełnione. Źródłem tego mogą być ograniczenia zewnętrzne (np. wpływ władzy lokalnej), subiektywne nadawcy przekazu czy periodyczność określonego medium $^{39}$. Prasa lokalna jest ważnym elementem systemu komunikacji społecznej. Dociera do szerokiej publiczności, co zostało wykorzystane już w 1996 i 1997 r. podczas kampanii na rzecz uchwalenia konstytucji, czy latem 1997 r. podczas powodzi ${ }^{40}$.

Czytelnicy pism lokalnych zapoznają się z prasą bezpośrednio lub pośrednio poprzez relacje innych osób o treści periodyków. Częściej kupują prasę lokalną ludzie mający około 40 lat i więcej, później przekazują ją członkom rodziny, sąsiadom i znajomym. Zatem lokalna prasa szeroko i aktywnie oddziałuje na świadomość społeczną. Czytelnicy w pierwszej kolejności szukają na łamach pism lokalnych informacji nie z urzędu, lecz tej która bezpośrednio dotyczy ich samych lub ich znajomych. Argumenty ekonomiczne i socjologiczne inicjatyw lokalnych wydają się trwalsze niż te, które przesądzają o istnieniu prasy obejmującej kilka województw. W związku tym czasopisma ogólnopolskie, a zwłaszcza regionalne coraz częściej zakładają swoje mutacje w środowiskach lokalnych bądź partycypują w udziałach prywatnych pism lokalnych. Zjawisko to wcale nie musi eliminować tytułów już ukazujących się w gminach i powiatach. Warto pamiętać, że ludzie cenią bardziej to co znają, a zatem przywiązują się do miejscowej prasy i popierają mniej lub bardziej dziennikarzy, których od wielu lat znają. Powstanie zatem konkurencyjnego tytułu to dobry impuls do zmiany wizerunku dotychczasowego pisma.

Prasa drukowana zdaje sobie sprawę, że cyberprzestrzeń staje się potentatem na newsy i zyskuje przywilej komentowania i wyjaśniania. $\mathrm{W}$ rezultacie ekonomizacja dziennikarstwa, urynkowienie pracy w mediach (np. poprzez samo zatrudnienie dziennikarzy czy działających na rzecz kilku redakcji) mające wpływ na jakość oferowanego produktu, spowodowały, że ciężar informacyjny przesuwa się w stronę komunikacji on-line. Wydawcy w odpowiedzi na rosnącą konkurencję coraz częściej sięgają po nowe rozwiązania technologiczne. Wydania elektroniczne,

39 S. Michalczyk określił związki prasy samorządowej z władzą lokalną, wyróżniając trzy modele - model dyrektywno-cenzorski, doradczo-konsultacyjny oraz liberalno-partnerski. Szerzej: S. Michalczyk, Prasa samorzqdowa. Szkice prasoznawcze, Katowice 1996, s. 37.

40 A. K. Piasecki, op. cit., s. 145. 
strony i całe platformy internetowe są tego przejawem. $Z$ jednej strony e-wydania prasy lokalnej wspierają tradycyjne wydania tytułów. Z drugiej - stanowią też środek promocji oraz źródło informacji o redakcji, wydawcy i działalności reklamowej. Redakcje prasy lokalnej w porozumieniu z firmami informatycznymi częściej zakładają własne strony internetowe o nieskomplikowanej prezentacji pisma (np. „Gazeta Rawicka”), aniżeli korzystają z innych rozbudowanych platform Internetowych (np. „Gazeta Kościańska” ukazuje się na portalu Kościan.net. Portal Informacyjny, „Panorama Leszczyńska” i „Telewizja Leszno” w panorama.media.pl tworzone przez zespół $P L$, ,w Internecie” i agencję dziennikarską News Net). W większości postaci e-wydania są wyłącznie elektroniczną kopią wersji drukowanej, gdyż układ i zawartość serwisu w całości nawiązują do wersji tradycyjnej (np. „Przegląd Osiecki”, „Kurier Przemęcki”, „Wiadomości Jutrosińskie”). W związku z powyższym, w przypadku prasy lokalnej mamy do czynienia raczej z elektronicznymi wydaniami tytułów na zasadzie zeskanowania archiwalnych edycji całego czasopisma (np. „Nasze Jutro”, „Rydzyna Tu i Teraz”, „Witryna Śmigielska”, „Wieści Pępowa”) lub tylko strony tytułowej (np. „Głos Lipna”, „Życie Gminy Krzemieniewo”, „Wizja Lokalna”), a czasami i bieżących wydań („Przegląd Osiecki”, „Nowa Gazeta Gostyńska”). Portale informacyjne prasy ogólnopolskiej i regionalnej tworzą obecnie własne serwisy informacyjne, natomiast w prasie lokalnej ten etap dopiero się rozpoczął (np. „Życie Gostynia”, „Życie Rawicza”). W rezultacie większość wydawców traktuje e-wydanie jako alternatywny dostęp do swoich czytelników ${ }^{41}$. Co więcej - funkcjonuje z osobnym brandem i innym targem (np. panorama.media.pl). Za przygotowanie e-gazety odpowiadają najczęściej samodzielne zespoły redakcyjne. Wydawcy spodziewają się, że poprzez związek tradycyjnych mediów z Internetem i ich konwergencją, zwiększy się liczba czytelników (np. darmowy dostęp do e-archiwum w wyniku zakupu prenumeraty prasy drukowanej). Koszty dystrybucji on-line są niższe niż w przypadku dystrybucji tradycyjnej, choć oczywiście wymagają określonego nakładu kapitału na zasoby komputerowe, serwery i dzierżawy łączy telekomunikacyjnych ${ }^{42}$. Ważne jest również to, iż e-gazeta pozwala dokonywać na bieżąco oceny stopnia zainteresowania odbiorców poszczególnymi tematami i autorami (sondowanie opinii, możliwość zamiesz-

41 T. Kowalski, B. Jung, op. cit., s. 131.

42 Ibidem, s. 131-132. 
czania komentarzy przez czytelników). W ramach polityki kształtowania dobrego wizerunku tytułu drukowanego, można w nim zamieścić pozytywne opinie, zamieszczone w e-gazecie.

Obok prasy drukowanej w południowo-zachodniej Wielkopolsce funkcjonuje lokalne radio i lokalna telewizja kablowa. Dzielą one rynek z nadawcami regionalnymi takimi jak - Radio Eska $(102.0 \mathrm{MHz})$ i Radio Merkury (100,9 MHz), które to reprezentowane są przez tzw. lokalne redakcje $\mathrm{z}$ siedzibą w Lesznie ${ }^{43}$. Wspomniane rozgłośnie radiowe swoim zasięgiem obejmują obszar byłego województwa leszczyńskiego. Radio Eska ma dosyć rozbudowaną redakcję lokalną (15 dziennikarzy) w stosunku do skromnej reprezentacji Radia Merkury i jest zorientowana na młodego odbiorcę (12-36 lat). Tym samym doczekała się własnego młodzieżowego fanklubu ${ }^{44}$. Często występuje również w roli patrona medialnego różnego rodzaju imprez lokalnych. W Lesznie również od 1993 roku nadaje lokalne Radio Elka i swoim zasięgiem obejmuje obszar byłego województwa leszczyńskiego (Leszno, Kościan, Gostyń, Góra, Rawicz i Wschowa). W drugiej dekadzie funkcjonowania mediów - Radio Elka wkracza na rynek Dolnego Śląska. W tym okresie również dziennikarze Radia Elka nie poprzestają na przekazie radiowym i tworzą coraz to nowe specjalistyczne portale (portal - regiony elka.fm; elka tv. lokalny kanał video; moto.elka.fm, dom.elka.fm, ryby.elka.fm) oraz pismo drukowane powiatu leszczyńskiego - „Dodatek!” ukazujący się nakładem 14 tysięcy egzemplarzy ${ }^{45}$. Dziennikarze Radia Elki wykupili pakiet udziałów od leszczyńskiej spółki Akwawit i obecnie w postaci trzech spółek dowodzą całym przedsiębiorstwem medialnym $\mathrm{w}$ myśl konwergencji mediów ${ }^{46}$. Wydawca Radio Elka stworzył podobną ofertę dla Głogowa, Polkowic, Lubina i Legnicy (woj. dolnośląskie) w postaci radia (Radio Elka) i portalów zagłębia miedziowego (miedziowe.pl, miedziowe.tv lokalny kanał video, moto.miedziowe.pl, dom.miedziowe.pl, ryby.elka.pl) ${ }^{47}$. Zdaniem red. J. Zielonki z „Panoramy Leszczyńskiej” - Radio Elka to ,[...] dziecko sukcesu [...] odbiera je [...] milion osób" (poza portalami) ${ }^{48}$. Póki co

43 http://www.eska.pl/pracownicy; http://nadaje.com/Radio_Eska_Leszno.html; http://www.radiomerkury.pl/o-nas.html, odczyt 7.07.2011 r.

44 http://fanclub-eska-leszno.pl.

45 http://elka.pl, odczyt 5.07.2011 r.

$46 \mathrm{http}: / /$ elka.pl//content/view/49792/80, odczyt 9.06.2011 r.

47 http://www.miedziowe.pl, odczyt 5.07.2011 r.

48 http://elka.pl//content/view/49792/80, odczyt 9.06.2011 r. 
rynek prasy drukowanej południowo-zachodniej Wielkopolski nie chyli się ku upadkowi. Obecnie jest jeszcze miejsce na inicjatywy w tradycyjnym znaczeniu obok rozwijających się nowych mediów. W skład tych ostatnich wchodzi także telewizja internetowa, często powielająca przekaz telewizji kablowej funkcjonującej na terenie Leszna, Gostynia i Rawi$\mathrm{cza}^{49}$. Lokalna leszczyńska telewizja kablowa Telewizja Leszno, nadawana jest w sieci UPC (podobnie jak telewizja z Gostynia) oraz w sieci śródmiejskiej od 1992 roku. Od dnia 15 grudnia 2008 roku Telewizja Leszno jest również dostępna na terenie Rawicza.

Najważniejsze zmiany na rynku prasy lokalnej w południowo-zachodniej Wielkopolsce miały miejsce w latach 1990-1999. Rynek prasy samorządowej, ośrodków i towarzystw kulturalnych oraz wydawnictw prywatnych rozwinął się w pierwszej połowie lat dziewięćdziesiątych. Natomiast gazetki parafialne i szkolne powstawały w okresie od 1997 do 1998 r., z których część ulega likwidacji w 1999 roku. Nie były wydawane w latach 1990-1999 pisma mniejszości narodowych, osiedlowe i zakładowe. W latach 1995-1999 tytuły samorządowe stały się konkurencyjne dla wydawnictw prywatnych, rozszerzając na swoich łamach problematykę społeczną. Na rynku wydawniczym utrzymały się pisma z jednej strony zakorzenione w historii regionu, a z drugiej - otwarte na nowe tendencje redagowania tytułów lokalnych i analizowania współczesnych problemów południowo-zachodniej Wielkopolski. Redakcje prasy lokalnej, aby przetrwać na rynku wydawniczym, wyszły naprzeciw oczekiwaniom czytelników, biorąc pod uwagę formę i treść publikacji oraz szatę graficzną tytułów. Zasięg kolportażu do 1998 roku pokrywał się z granicami administracyjnymi miasta, gminy lub dawnego powiatu, od 1999 roku niektóre tytuły („Elita”, „Panorama Leszczyńska”, „Gazeta ABC”, „Słowo Ziemi Wschowskiej") w wyniku nowego podziału administracyjnego przyjęły charakter transgraniczny, obejmując swoim zasięgiem gminy i powiaty dotychczasowych wpływów, będące obecnie w granicach nowych województw (wielkopolskiego, dolnośląskiego i lubuskiego). Pod względem edytorskim również zaszły kolosalne zmiany. O ile w początkach lat dziewięćdziesiątych prasa lokalna w dużej mierze korzystała z tzw. „małej poligrafii””(zwykle ksero), to po 1995 roku czasopisma korzystały już z usług drukarni. Warto też zwrócić uwagę, iż okres wyborów

49 http://www.leszno24.pl/Co_zrobic_z_telewizja_kablowa_w_Lesznie?,6304.html; http://www.gg.bt.pl/info01_7/kabeltv.htm, odczyt 9.06.2011 $\overline{\mathrm{r}}$. 
jesienią 1998 roku nieco przypominał atmosferę z 1990 roku. Wtedy również tworzono kolejne instytucje samorządowe, powstawały nowe tytuły i ponownie usiłowano wzmocnić relacje redakcji prasowych z radnymi. W latach 2000-2010 tytuły z niskim kapitałem, mało profesjonalnym zespołem redakcyjnym, niesprawnym kolportażem, w obliczu braku reklamodawców (szczególnie w środowisku sublokalnym) nie utrzymały się na rynku wydawniczym. Problem ten dotyczył prasy powiatowej, nierzadko powstałej już w latach 1999-2002 jako efekt nowego podziału administracyjnego [„Nowa Elita”, „Wschowskie Wiadomości” (2000-2001) czy „Ziemia Wschowska” (2000)]. Podobnie rzecz miała się z biuletynami samorządowymi, które zapisały się w historii regionu tylko jako efemerydy (np. „Kościańska Gazeta Samorządowa”, „Ziemia Borecka”). Większość obecnych czasopism południowo-zachodniej Wielkopolski to te, które działają od początku lat dziewięćdziesiątych, co świadczy już o stabilizacji rynku. Wiele z nich to niskonakładowe czasopisma sublokalne, które ukazują się pod patronatem władz lokalnych i nie posiadają konkurencyjnych tytułów. W dalszym ciągu mają charakter deficytowy i opierają się na niskopłatnym (w I poł. lat dziewięćdziesiątych działalność społeczna) zaangażowaniu zespołu (dodatek funkcyjny dla osób zatrudnionych w urzędzie). Niemniej trzeba oddać, iż w przypadku wielu pism lokalnych poprawiła się jakość wydawanych pism, na co wpływ miało doświadczenie wydawców, czerpanie przykładów z prasy ogólnopolskiej i regionalnej, ale też upowszechnia nowości z dziedziny poligrafii i informatyki. Do 2002 roku, do momentu wejścia w życie ustawy o dostępie do informacji publicznej, dochodziło do wielu spięć w relacjach między redakcją a urzędem, które kończyły się m.in. reglamentacją informacji w przypadku prasy opozycyjnej (np. „Gazeta Górowska”) czy zmianami personalnymi w redakcji, jeżeli pismo należało do samorządu (np. „Przegląd Górowski”). Ustawa problemu nie rozwiązała (ponad 2000 orzeczeń sądów administracyjnych), ale samorządy nie mogły już bezkarnie decydować o chociażby wybiórczym dopuszczaniu dziennikarzy do protokołów z posiedzeń rad i zarządów. Największa dynamika zmian w latach 2000-2010 dotyczyła zakładania elektronicznych wydań prasy lokalnej. Z kolei powstawanie stron internetowych miast, gmin i powiatów otwarło dyskusję nad kształtem polityki informacyjnej samorządów i jej miejsca na budowanie relacji z lokalnymi mediami (np. udzielanie odpowiedzi dziennikarzom, tworzenie serwisów informacyjnych, kalendariów wydarzeń, organizowanie konferencji dla prasy czy zamieszczanie dodatków samorządowych w prasie lokalnej). W omawia- 
nym okresie widoczne były szczególnie procesy koncentracyjne na rynku prasy regionalnej, gdzie ukształtował się swoisty duopol tworzony przez spółki Media Regionalne i Polskapresse. Z drukarni tej ostatniej, jak już wspomniano - licznie korzystają lokalne tytuły południowo-zachodniej Wielkopolski oraz powiatu górowskiego (woj. dolnośląskie) i wschowskiego (woj. lubuskie).

Rozwój prasy lokalnej może być generowany przez różnego rodzaju działania marketingowe w kierunku zachęcenia mieszkańców regionu do jej czytania (i tym samym kupna), nie akcentując na konkretny tytuł (na zasadzie idei np. - czytamy książki i prasę). W taką inicjatywę powinny włączyć się wszystkie podmioty zaangażowane w rynek lokalny, poczynając od przedstawicieli władz, poprzez media (marketing medialny) i reklamodawców, a kończąc na organizacjach społecznych. Na odbiorze prasy lokalnej powinny skorzystać wszystkie te segmenty łącznie z wydawca, jak i czytelnicy, pod warunkiem, że otrzymają tytuł profesjonalnie wykonany. Ranga informacji lokalnej wzrosła w drugiej dekadzie funkcjonowania prasy ogólnopolskiej i regionalnej. Jak zwracają uwagę medioznawcy, praktycznie wszystkie dzienniki ogólnopolskie i regionalne mutują swoje wydania terenowe $\mathrm{e}^{50}$. Obok redakcji wydającej grzbiet główny, istnieje kilka do kilkunastu redakcji regionalnych, w których to najliczniej reprezentowana jest informacja lokalna. Systematyczne badania zachowań czytelniczych wskazują, że największym zainteresowaniem cieszą się właśnie informacje lokalne. Wydawcy mediów ogólnopolskich i regionalnych docenili znaczenie lokalnego czytelnika również pod kątem rynku reklamowo-ogłoszeniowego. Okazuje się, że rynek lokalnego reklamodawcy nie jest dostatecznie zagospodarowany przez media lokalne i sublokalne. Warto też odnotować, że obok tradycyjnie zamieszczanych treści informacyjnych i publicystycznych opisujących życie lokalne na poziomie politycznym, społecznym i obywatelskim, można byłoby publikować problematykę zgłaszaną przez czytelników w zakresie dostępu do informacji w Polsce, jak i dostępu do dokumentów instytucji UE. Zarzuty niewłaściwego administrowania pod kątem braku dostępu do informacji są na pierwszym miejscu podkreślane w sprawozdaniach Rzecznika Praw Obywatelskich i europejskiego Ombudsmana ${ }^{51}$. Te kwestie nie muszą

50 M. Kaczmarczyk, op. cit., s. 155.

$51 \mathrm{http} / /$ www.ombudsman.europa.eu/activities/annualreports.faces, odczyt 5.07.2011 r. 
być tylko domeną prawników i naukowców, ale jak już wskazują sprawozdania KE rośnie zainteresowanie tą tematyką dziennikarzy ${ }^{52}$. Taki swoisty rodzaj poradnictwa mógłby uwiarygodnić pozycję pisma, iż stoi ono po stronie obywatela, a nie tylko zamieszcza publikacje wspierające bezpośrednio czy pośrednio lokalne elity. Oczywiście dziennikarze będą wypełniać raczej funkcję informacyjną i edukacyjną w tym wymiarze, aniżeli interwencyjną sensu stricto.

Należy również zgodzić się z poglądem S. Dzikiego i W. Chorązkiego, iż media lokalne przeszły trzy etapy rozwoju: heroiczno-społecznikowski, polityczny i rynkowy, a ich przyszłość zależeć będzie od takich elementów, jak: zasobności wydawcy i możliwości finansowania deficytu prasy, profesjonalizmu zespołu redakcyjnego oraz marketingowego, wielkości i rodzaju rynku odbiorców i reklamodawców oraz sprawności kolportażu ${ }^{53}$. Warto też rozwiać obawy o zmierzchu drukowanej prasy lokalnej, pojawiające się po 2002 roku, a związane z nagłym rozwojem nowych mediów. W rezultacie elektroniczne wydania prasy lokalnej nie cieszą się tak dużym zainteresowaniem, jak się spodziewano ${ }^{54}$. Badania ankietowe przeprowadzone w 2010 roku przez PBC (Polskie Badania Czytelnictwa) pokazały, że wszystkie media mają swoje miejsce na rynku i każde z nich jest inaczej konsumowane ${ }^{55}$. Interesujące są zwłaszcza cechy wymagane od poszczególnych mediów. Zatem drukowana prasa lokalna powinna być tworzona jasnym i zrozumiałym językiem, treść publikacji winna być zgodna z rzeczywistością i tworzona przez wiarygodnych ludzi. Istotna jest możliwość powrotu do treści oraz hierarchiczny układ treści. Poza tym mile widziane są dodatki i wszelkie gadżety uzupełniające pismo. Prasa lokalna powinna być medium informacyjnym, gdyż rola opiniotwórcza tytułu - zdaniem respondentów - należy do dzienników ogólnopolskich. Wydaje się zatem, że czytelnik sam potrafi ocenić wydarzenia i zjawiska mające miejsce w środowisku lokalnym, doskonale mu znanym. Inne badania czytelnictwa z 2003 r. (Lokalne Badania

52 http://www.europarl.europa.eu/RegData/PDF/439692_1_PL.pdf, odczyt 5.07.2011 r.

3 S. Dziki, W. Chorązki, Media lokalne i regionalne, w: Dziennikarstwo, op. cit., s. 138.

${ }_{54}$ R. Polak, Prasa lokalna i sublokalna w województwie podkarpackim, w: Media lokalne a demokracja lokalna, pod red. J. Chłopeckiego, R. Polaka, Rzeszów 2005, s. 164.

${ }_{55} \mathrm{http}: / /$ www.pbczyt.p/badanie/items/90.html, odczyt 5.07.2011 r. 
Społeczne) udowodniły, iż prasa lokalna w mniejszych aglomeracjach miejskich i na wsiach przeważa nad ogólnopolską ${ }^{56}$. Wiele osób nie czyta żadnej innej prasy - poza lokalną. Co więcej informacja lokalna jest najważniejszym powodem do sięgania po tytuły lokalne. Odbiorcami są osoby z różnych grup wieku, płci, wykształcenia czy dochodów ${ }^{57}$. Z drugiej strony ciekawe są też oczekiwania samych dziennikarzy od mediów lokalnych. Cenną informacją są prace nadsyłane w różnych konkursach dziennikarstwa lokalnego. Materiały na konkurs dotyczą zazwyczaj kronikarskich zapisków konfliktów, także materiałów interwencyjnych, jak również emocjonalnych zapisów zachowań czy historycznych kontekstów. Jednak Jury chciałoby, aby redakcje prasy lokalnej w swoich tytułach promowały pomysły na teksty służące lokalnym społecznościom, wyróżniały próby odejścia od dziennikarskich schematów, popularyzowały wartki język narracyjny i poprawną polszczyznę i wyszukiwały ciekawe formy prezentowania osobliwości „małych ojczyzn”, a zwłaszcza pokazywały pozytywny obraz Polski lokalnej ${ }^{58}$.

W kontekście powyższych rozważań media lokalne są ważnym elementem integrującym społeczność lokalną wokół idei, problemu czy wydarzenia, a ich głównym motorem jest informacja lokalna w mniej lub bardziej profesjonalnym wydaniu - w zależności od oczekiwań odbiorcy i sztuki dziennikarskiej. Informacja lokalna - patrząc w przyszłość - bez względu na rodzaj nośnika, zawsze będzie poszukiwanym towarem. Współcześnie wydaje się również, że byt drukowanej prasy lokalnej jest społecznie zapewniony. Dowodem tego może być aktualna kondycja mediów lokalnych południowo-zachodniej Wielkopolski i jej okolic.

\section{Two decades of transformations in the local media of south-and-east Wielkopolska}

\section{Summary}

The Republic of Poland is assumed to have been born in 1989, which also marks the beginning of the transformations in the Polish media market. After twenty years

56 http://www.lokalnebadania.com/wp-content/uploads/2010/02/prasa-lokalna-i-regionalna-jako-element-spoleczenstwa-obywatelskiego, odczyt $5.07 .2011 \mathrm{r}$.

57 Także: M. Jóźko, Prasa lokalna i regionalna jako element społeczeństwa obywatelskiego, w: Media lokalne a demokracja lokalna, pod red. J. Chłopeckiego, R. Polaka, Rzeszów 2005, s. 117.

58 http://www.spl.top.pl/konkursy_VIIISPL2007_1.html, odczyt 5.05.2011 r. 
some conclusions on the directions of the development of the media can be reached. The field of research discussed in this paper involves the media of south-and-east Wielkopolska and adjacent districts, connected with Wielkopolska in historical, cultural and economic terms. The results of this research attempt to present a systemic description of the local media, including their emergence, development and evolution. The discussion encompasses the legal, political, organizational, technical, and economic conditions for issuing and propagating the media. Given the diversified typology of the media in the region under analysis, the specificity of local mass media is confirmed. 
